\title{
Establishing a food web model for coastal Antarctic benthic communities: a case study from the Vestfold Hills
}

\author{
C. L. Gillies ${ }^{1,2,3, *}$, J. S. Stark ${ }^{2}$, G. J. Johnstone ${ }^{2}$, S. D. A. Smith ${ }^{1}$ \\ ${ }^{1}$ National Marine Science Centre, Southern Cross University, Coffs Harbour, New South Wales 2450, Australia \\ ${ }^{2}$ Australian Antarctic Division, Channel Hwy, Kingston, Tasmania 7050, Australia \\ ${ }^{3}$ Present address: Earthwatch Australia, 126 Bank St, South Melbourne, Victoria 3205, Australia
}

\begin{abstract}
Shallow-water benthic communities throughout coastal Antarctica share many species and are governed by similar physico-oceanographic processes. This suggests community structure and function may be similar among communities despite being geographically separated by up to 15 degrees of latitude and $18000 \mathrm{~km}$ of coastline. To test this theory, we developed a food web model using stable isotopes $\left(\delta^{13} \mathrm{C}, \delta^{15} \mathrm{~N}\right)$ for the high-latitude Vestfold Hills shallowwater benthic community and compared it to the isotopic food web model developed for the Windmill Islands, located over $1000 \mathrm{~km}$ away. For the Vestfold Hills food web, carbon sources were generally well separated by $\delta^{13} \mathrm{C}$, and lower-order consumers could be grouped according to their feeding guild and main dietary sources as determined by $\delta^{13} \mathrm{C}$ and $\delta^{15} \mathrm{~N}$. Higher-order consumers occupied the full range of $\delta^{13} \mathrm{C}$ ratios and had similar $\delta^{15} \mathrm{~N}$ values, although predators were weakly, but significantly, enriched in $\delta^{15} \mathrm{~N}$ compared to scavenger/predators and omnivores. When comparing with the Windmill Islands food web, we found similar $\delta^{13} \mathrm{C}$ ratios for several cooccurring carbon sources and consumers, whilst the $\delta^{15} \mathrm{~N}$ ratios in consumers from the Vestfold Hills were consistently enriched compared to those from the Windmill Islands by 1 to $2 \%$. The relative positions of feeding guilds on the $\delta^{13} \mathrm{C}$ and $\delta^{15} \mathrm{~N}$ planes were similar for both food webs. These results suggest there is considerable merit in developing a representative food web model for Antarctic shallow-water communities. Such a model would provide a trophic benchmark against which modification in these communities brought about by climate change or other human impacts could be compared.
\end{abstract}

KEY WORDS: Energy flow · Trophic ecology · Casey Station · Davis Station · Windmill Islands · Stable isotope analysis

\section{INTRODUCTION}

Understanding carbon flow and trophic linkages in the context of a food web is a fundamental requisite in determining future ecosystem-wide changes to community structure and function (Polis 1994, Post 2002). The need for such understanding is particularly imperative in the Antarctic, where impending changes in climate are expected to bring about largescale changes to the environment. For example, changes to air and water temperatures, induced by climate change, are likely to bring about altered sea ice cover and consequently affect light regimes and primary productivity (Stammerjohn et al. 2008). Bottom-up changes in carbon resources may lead to direct changes in the distribution and abundance of benthic fauna, significantly altering the structure and function of benthic communities (Massom \& Stammerjohn 2010). Understanding the links between carbon sources and consumers is also central to detect- 
ing bottom-up changes to contamination pathways (Hobson et al. 2002, Macdonald et al. 2005) and determining the top-down effects of the removal of large predators (Barbraud \& Weimerskirch 2001).

There is considerable evidence indicating that shallow-water (i.e. $<50 \mathrm{~m}$ ) benthic communities share similar features and are governed by similar physico-oceanographic processes throughout Antarctica. This is despite being geographically separated by up to 15 degrees of latitude and $18000 \mathrm{~km}$ of coastline. For example, many of the flora and fauna that occupy the shallow waters on the Antarctic Peninsula also occur at higher latitudes (Dayton et al. 1994, Gambi et al. 1994, Barnes et al. 2006, Gutt 2007), with both regions governed by strong seasonality in primary production (Clarke 1988, Quartino \& Boraso de Zaixso 2008) and having similar ice disturbance regimes (Gambi et al. 1994, Barnes 1999). Climatic conditions in terrestrial habitats may be milder on the Peninsula compared to the continent, but differences in ocean temperature are much smaller, varying by less than $3^{\circ} \mathrm{C}$ between the Antarctic Peninsula and higher latitudes (Clarke 1988, Peck 2005). The similarity in fundamental community and ecosystem properties suggests carbon flow and trophic processes may also be similar for many shallow-water benthic communities throughout Antarctica. Yet currently, our ability to identify generalised patterns in food web structure for the Antarctic shallow-water region is considerably hampered by (1) the paucity of descriptions of coastal food webs or carbon flow from high-latitude areas and regions outside of the Antarctic Peninsula or the Ross Sea; and (2) the lack of comparative studies.

No study to date has identified consistent patterns in benthic food web dynamics across similar communities from different regions in Antarctica. This is despite the development of several models describing carbon flow and trophic associations for shallowwater benthic communities (Dunton 2001, Corbisier et al. 2004, Jacob et al. 2006) and a growing body of literature indicating that Antarctic shallow-water food webs share similar patterns of resource use and trophic width (Dayton et al. 1974, Dayton \& Oliver 1977, Kaehler et al. 2000, Dunton 2001, Corbisier et al. 2004, Jacob et al. 2006). The current lack of comparative studies limits our ability to model the effects of large-scale impacts beyond the regional scale and, therefore, identify consistent patterns brought about by large-scale processes. Additionally, the identification of spatial consistencies amongst food webs from different regions will allow greater insight into the application of food web theory to Antarctic systems and, consequently, allow studies from the Antarctic to contribute to food web theory.

Current understanding of shallow-water food webs from Antarctic shallow-water benthic communities suggests they are characterised by a high level of consumer connectivity, indicated by a high degree of omnivory, in response to strong seasonality in the timing and quantity of primary production (Arntz et al. 1994, Dayton et al. 1994, Barnes \& Clarke 1995). Feeding plasticity at all trophic levels in response to variable carbon sources points towards considerable food web complexity (Jacob et al. 2006, Norkko et al. 2007). A lack of discernible trophic levels (Kaehler et al. 2000, Corbisier et al. 2004, Gillies et al. 2012b) suggests food chains in shallow-water benthic food webs are more representative of a trophic 'continuum' (France et al. 1998) rather than traditional stepwise trophic models (Hairston et al. 1960). Thus Antarctic shallow-water food webs may represent relatively stable systems, summarised by strong connectivity and weak interactions between food web members (McCann 2000).

The Vestfold Hills and Windmill Islands lie approximately $1000 \mathrm{~km}$ apart in Eastern Antarctica and are part of Antarctica's small ice-free coastal zone, estimated to occupy only $0.01 \%$ of Antarctica's coast (Snape et al. 2001). Whilst rare, these areas constitute important breeding and haul-out areas for many birds and mammals (Murray \& Luders 1990), are generally associated with human occupation (e.g. Davis, Casey stations) and represent important sources of shallow-water benthic production. Many common, circumpolar species occur at both locations and the numerous shallow bays and coastal islands support a mixture of suspension-feeding and algaeherbivore communities (Tucker \& Burton 1987, Johnston et al. 2007). Consequently, they represent important geographic locations amongst the commonly featureless coastal regions of East Antarctica.

We used stable isotopes of carbon and nitrogen to identify carbon flows and trophic structure within the shallow-water benthic ecosystem of the Vestfold Hills. Our primary goal was to build a conceptual food web model derived from stable isotopes of carbon and nitrogen for the shallow-water benthic community from the Vestfold Hills and to (1) identify the main carbon sources utilised by the benthic fauna; and (2) provide estimates of trophic position. We then tested the generality of our food web with the isotopic model developed for the Windmill Island food web by Gillies et al. (2012b), by comparing the isotopic values of co-occurring carbon sources and consumers and the isotopic position of each trophic guild within the food web. 


\section{MATERIALS AND METHODS}

\section{Study locations}

The Vestfold Hills lie at $68^{\circ} 35^{\prime} \mathrm{S}, 77^{\circ} 58^{\prime} \mathrm{E}$ in Prydz Bay, Princess Elizabeth Land (Fig. 1). The area is bound by the Sorsdal Glacier in the south and the Antarctic Plateau $24 \mathrm{~km}$ to the north. The region is surrounded by low-lying rocky hills, indented by 3 large fjords and several smaller bays and inlets. A number of small, rocky islands lie in close proximity to the coast. The area supports a rich benthic community (Tucker \& Burton 1987), comparable with that of similar habitats from other parts of Antarctica (Tucker \& Burton 1988). Winter sea ice breaks out in late spring (November to December), with the area relatively ice free from January to March.

The Windmill Islands are located at $66^{\circ} 17^{\prime} \mathrm{S}$, $110^{\circ} 31^{\prime} \mathrm{E}$ in Wilkes Land $(1000 \mathrm{~km}$ east of the Vestfold Hills) in close proximity to the Vanderford Glacier. Spanning an area of $30 \mathrm{~km}$ along the coastline, the region is characterised by 50 islands, with 5 main peninsulas jutting out from the Antarctic Plateau. The peninsulas comprise low rocky hills with intervening snow-covered valleys and meet the water's edge with a mix of low ice edges and rocky shores. In general, patches of bedrock and boulders occur at shallow depths near the shore, with the substrate sloping down to finer grades of sediment. The benthic fauna is comparable to other nearshore locations within Antarctica (Johnston et al. 2007). Winter seaice breaks out sporadically over the summer months (December to February), leaving a mosaic of ice-free and ice-covered areas during the summer period.

\section{Sampling design}

We sampled several benthic macroalgae, in addition to pelagic particulate organic matter (POM), sediment POM, sea ice POM, and consumers from several different locations (Fig. 1) occupying the shallow, nearshore zone (0 to $30 \mathrm{~m}$ ) around the Vestfold Hills, in the summer season from December 2009 to March 2010. Samples were collected from 20 sites visited once over the 4 mo sampling period. Consumers were collected as close to their potential food sources as recommended by Gillies et al. (2012a), with the exception of sea ice algae which was sampled prior to winter sea ice break out (midDecember) with sampling sites chosen to represent a mixture of nearshore and offshore locations. All sampling sites were within a $5 \mathrm{~km}$ radial distance of

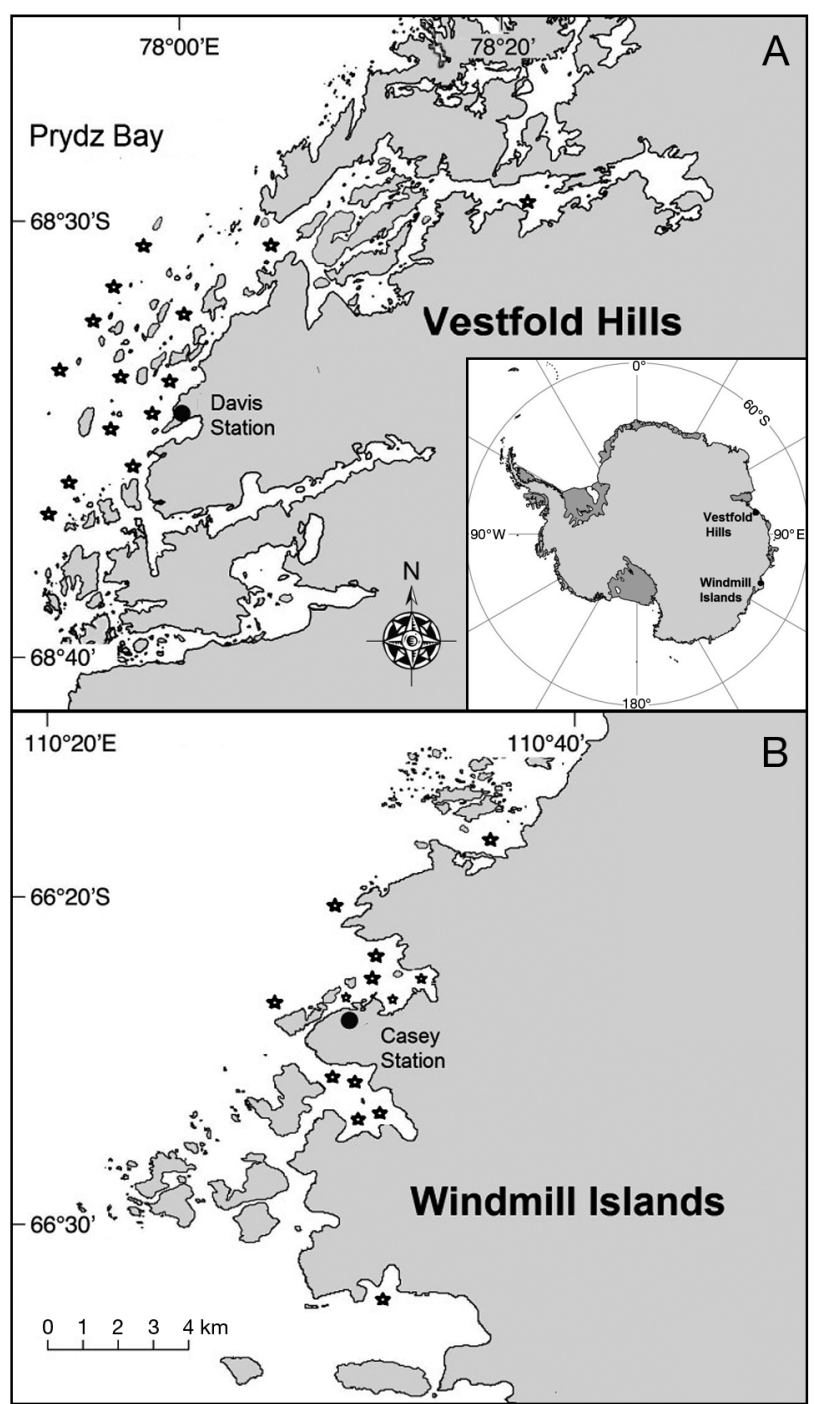

Fig. 1. Location of the (A) Vestfold Hills and (B) Windmill Islands. locations where samples were obtained

Davis Station, although we were careful not to sample within $500 \mathrm{~m}$ of the sewerage outfall to avoid potential contamination of isotope values. We aimed to collect many species across a range of feeding guilds in order to describe carbon flows and trophic pathways amongst the general benthic community.

\section{Carbon sources}

Sediment POM samples were collected by divers throughout the sampling period at depths of 6 to $30 \mathrm{~m}$ by coring ( $5 \mathrm{~cm}$ diameter by $10 \mathrm{~cm}$ long) and utilising only the top $1.5 \mathrm{~cm}$ section of the core. Larger infauna were removed prior to drying and an homogenised sediment POM sub-sample (representing a mixture of 
carbon sources) was analysed. Macroalgal samples were collected by divers and kept dark until frozen for analysis. Pelagic POM samples were collected by monthly (January to March) horizontal tows conducted at the surface, adjacent to the coast (53 $\mu \mathrm{m}$ mesh, $100 \mathrm{~m}$ from shore). Samples were dominated by the diatom Trigonium antarcticum and dinoflagellates. Sea ice POM samples were collected from fast ice adjacent to the coast by a SIPRE corer and comprised a mixture of diatoms and bacteria. Both pelagic POM and sea ice POM samples were kept dark in the field at approximately $-4^{\circ} \mathrm{C}$ until they were brought back to the laboratory. Samples were then scanned under a dissecting microscope to remove large zooplankton and spun in a centrifuge at $3400 \mathrm{rpm}$ for $10 \mathrm{~min}$ : the supernatant was discarded and the remaining sample rinsed with Milli-Q water, re-spun, dried and frozen at $-20^{\circ} \mathrm{C}$ for subsequent analysis.

\section{Consumers}

All consumers with the exception of fish, tanaids, amphipods and nephtyid polychaetes, were collected by divers at depths between 2 and $30 \mathrm{~m}$ and by snorkelling at depths down to $2 \mathrm{~m}$. Fish were collected with a long line or in baited traps between 8 and $30 \mathrm{~m}$. Tanaids, amphipods and nephtyid polychaetes were either sieved from the sediment cores, collected from the fish traps (amphipods) or collected using a dip net in waters $<2 \mathrm{~m}$. All samples were frozen at $-20^{\circ} \mathrm{C}$ until analysis. Reference specimens of ascidians, holothurians and sponges are held at the Australian Antarctic Division, Hobart.

\section{Stable isotope analysis}

Several tissue types were selected for stable isotope analysis amongst the benthic fauna (see Tables S1 \& S2 in the supplement at www.int-res.com/articles/ suppl/m478p027_supp.pdf). Where possible, muscle tissue was prioritised, followed by epidermal tissue, body sections and whole organisms (gut contents not removed). All samples were thoroughly rinsed in Milli-Q water prior to being dried in an oven at $60^{\circ} \mathrm{C}$ for $48 \mathrm{~h}$ and ground to a fine powder. Carbonates were removed from those samples where it was not possible to obtain carbonate-free tissue (asteroids, holothurians, ophuroids, echinoids, crustaceans, and sediment POM). Carbonates were removed with $1 \mathrm{M}$ $\mathrm{HCl}$ using the 'drop-by-drop' method recommended by Jacob et al. (2005).
Lipids can be depleted in $\delta^{13} \mathrm{C}$ by up to $9 \%$ relative to muscle tissue (DeNiro \& Epstein 1977). Consequently, to standardise lipid content amongst different tissue types, a post hoc mathematical normalisation formula was applied to $\delta^{13} \mathrm{C}$ values in samples where lipid content was high (Post et al. 2007). We used the $\mathrm{C}: \mathrm{N}$ ratio of samples as a proxy for lipid content, and where C:N exceeded 3.5 (i.e. high lipid content), applied the formula (Post et al. 2007):

$$
\delta^{13} \mathrm{C}=-3.32+0.99 \times \mathrm{C}: \mathrm{N}
$$

The mean difference between $\delta^{13} \mathrm{C}_{\text {lipid }}$ and $\delta^{13} \mathrm{C}_{\text {norm }}$ was: $0.95 \%$ o 0.05 ( \pm 1 standard error, $n=229$ ).

Prior to the main stable isotope analysis, and due to the difficulty in obtaining low or carbonate-free tissue samples, we conducted a pilot study to determine $\delta^{13} \mathrm{C}$ similarity between different tissue types in asteroids. We noted an increasing enrichment of $\delta^{13} \mathrm{C}$ amongst different tissue types after carbonate extraction and lipid normalisation (epidermis > tube feet $>$ intestinal tissue, C. Gillies unpubl. data). We therefore report $\delta^{13} \mathrm{C}$ values of asteroid tissue (and potentially echinoids and ophuroids) with the caveat that epidermal $\delta^{13} \mathrm{C}$ values may be enriched by $2.14 \%$ to $3.20 \%$ compared to other tissues, even despite carbonate removal and lipid normalisation. For $\delta^{15} \mathrm{~N}$, intestinal tissue was approximately $2 \%$ depleted compared to epidermal and tube feet tissue, which shared similar $\delta^{15} \mathrm{~N}$ values. We chose to use epidermal tissue in this study for consistency with other Antarctic studies that have used epidermal/body wall tissue in echinoderms (Jacob et al. 2006, Norkko et al. 2007, Mincks et al. 2008, Gillies et al. 2012b) but highlight the need for further investigation into isotope variability between different tissue types for Antarctic echinoderms.

Carbon $\left(\delta^{13} \mathrm{C}\right)$ and nitrogen $\left(\delta^{15} \mathrm{~N}\right)$ values were analysed by a continuous-flow stable isotope ratio mass spectrometer (Fisons Isochrom) coupled to an element analyser at the Research School of Biology, Australian National University, Canberra. The working standards used for $\delta^{13} \mathrm{C}$ were $\mathrm{C}_{3}$ beet sucrose and $\mathrm{C}_{4}$ cane, calibrated against the global standard Vienna PeeDee Belemnite (VPDB), whilst several synthetic standards were used for $\delta^{15} \mathrm{~N}$, calibrated against the global standard of atmospheric nitrogen. Standard deviations of replicate samples $(\mathrm{n}=149$ ) were $0.09 \%$ or for $\delta^{13} \mathrm{C}$ and $0.14 \%$ for $\delta^{15} \mathrm{~N}$.

Results are expressed in the standard delta notation:

$$
\delta X=\left(\left[R_{\text {sample }} / R_{\text {standard }}-1\right) \times 1000\right.
$$

where $X$ is carbon or nitrogen and $R$ is the ratio of the heavy isotope over the light isotope. 


\section{Data analysis}

Animals were separated by taxon and feeding guilds and plotted in $\delta^{13} \mathrm{C}$ versus $\delta^{15} \mathrm{~N}$ bi-plots to visualise differences in diet and trophic position. To test for differences in $\delta^{13} \mathrm{C}$ and $\delta^{15} \mathrm{~N}$ amongst feeding guilds and carbon sources, we used PERMANOVA, a permutation-based analogue of ANOVA, on a Euclidian distance similarity matrix. PERMANOVA is more suited to unbalanced data sets and has fewer assumptions than a standard ANOVA (Anderson 2001). To distinguish differences between individual feeding guilds and carbon sources, we subsequently analysed groups using pairwise comparisons. Significance levels were lowered to $p=0.01$ due to initial concern of incurring Type I error rates when analysing multiple pairwise comparisons (Underwood 1997). Post hoc sequential Bonferroni adjustments were deemed too conservative for our analyses (Moran 2003).

As temporal variation in primary producer $\delta^{15} \mathrm{~N}$ values can affect the estimated trophic position of higher order consumers (Cabana \& Rasmussen 1996, Post 2002), we used the $\delta^{15} \mathrm{~N}$ values of the longliving, sedentary suspension feeder Laternula elliptica as a baseline estimate of trophic position. We assumed a $\delta^{15} \mathrm{~N}$ trophic fractionation of $3 \%$, based on previous work (Vander Zanden \& Rasmussen 2001, Post 2002).We calculated a $\delta^{13} \mathrm{C}$ fractionation of $0.3 \%$ per trophic level based on the mean difference between suspension feeders and pelagic POM from this study.

The $\delta^{13} \mathrm{C}$ and $\delta^{15} \mathrm{~N}$ values of co-occurring carbon sources and consumer species that are common to both the Vestfold Hills and Windmill Islands were compared statistically using a $t$-test (Quinn \& Keough 2002). Furthermore, we compared our isotopic biplot to the trophic model produced by Gillies et al. (2012b) and identified similarities in trophic position of common food web members and the position of feeding guilds.

\section{Nomenclature}

We define 'trophic level' as a generalised term describing the step-wise, discreet functional position of a consumer or feeding guild within the food web (i.e. TL2 = first order consumers [herbivores], TL3 = second order consumers [predators], etc.) and use the term 'trophic position' to represent a more precise (continuous) description of a consumer's trophic position within a food web.

\section{RESULTS}

\section{Vestfold Hills food web}

A total of 82 consumer species and 9 carbon sources were sampled for the Vestfold Hills food web, covering a wide range of taxonomic groups and feeding guilds (Tables S1 \& S2 in the supplement). Species designated into feeding guilds separated into distinct isotopic groups when analysed using both $\delta^{13} \mathrm{C}$ and $\delta^{15} \mathrm{~N}$ values $\left(F_{5,436}=138.25, \mathrm{p}=0.001\right.$, see Fig. 6A) indicating feeding guilds were useful in categorising species into their respective trophic position within the food web.

$$
\delta^{13} \mathrm{C} \text { and } \delta^{15} \mathrm{~N} \text { in carbon sources }
$$

All carbon sources showed considerably different isotopic values, with pelagic POM, sediment POM and sea ice POM being well separated in $\delta^{13} \mathrm{C}$ and $\delta^{15} \mathrm{~N}$ from benthic macroalgae (Tables S1 \& S2 in the supplement, Figs. 2 \& 6A). Results of PERMANOVA and pairwise comparisons for $\delta^{13} \mathrm{C}$ indicated distinct separation amongst sediment $\mathrm{POM}$, sea ice POM, pelagic POM and macroalgae $(\mathrm{p}<0.01)$, whilst there was no separation amongst individual macroalgae ( $p$ > 0.05), except for the red alga Gymnogongrus sp., which had the least enriched $\delta^{13} \mathrm{C}$ value of all carbon sources $(-30.13 \%)$. Pelagic POM $(-19.86 \%)$ and sediment POM $(-18.68 \%)$ were relatively depleted compared to sea ice POM $(-8.79 \%)$. The remaining 5 macroalgal species, consisting of 2 red, 2 green and 1 brown algae, shared similar mean $\delta^{13} \mathrm{C}$ values ranging from $-17.70 \%$ for the green alga Monostroma sp. to $-16.33 \%$ for the red alga Palmaria decipiens. With the exception of sea ice POM $(2.95 \%)$ and Gymnogongrus sp. $(4.58 \%$ ), all carbon sources had enriched $\delta^{15} \mathrm{~N}$ values for producers relative to atmospheric nitrogen, ranging from $5.36 \%$ for the brown algae Himantothallus grandifolius to $6.80 \%$ for the red algae Iridaea cordata (Tables S1 \& $\mathrm{S} 2$ in the supplement, Figs. $3 \& 6 \mathrm{~A}$ ).

\section{$\delta^{13} \mathrm{C}$ in consumers}

The $\delta^{13} \mathrm{C}$ ratios amongst all fauna spanned a range of $13.74 \%$ and all consumers were within the $\delta^{13} \mathrm{C}$ range of sampled carbon sources. PERMANOVA analysis confirmed suspension feeders were isotopically distinct from the other first-order consumers (grazers and deposit feeders, $\mathrm{p}<0.01$ ), although there was considerable variation within each guild 


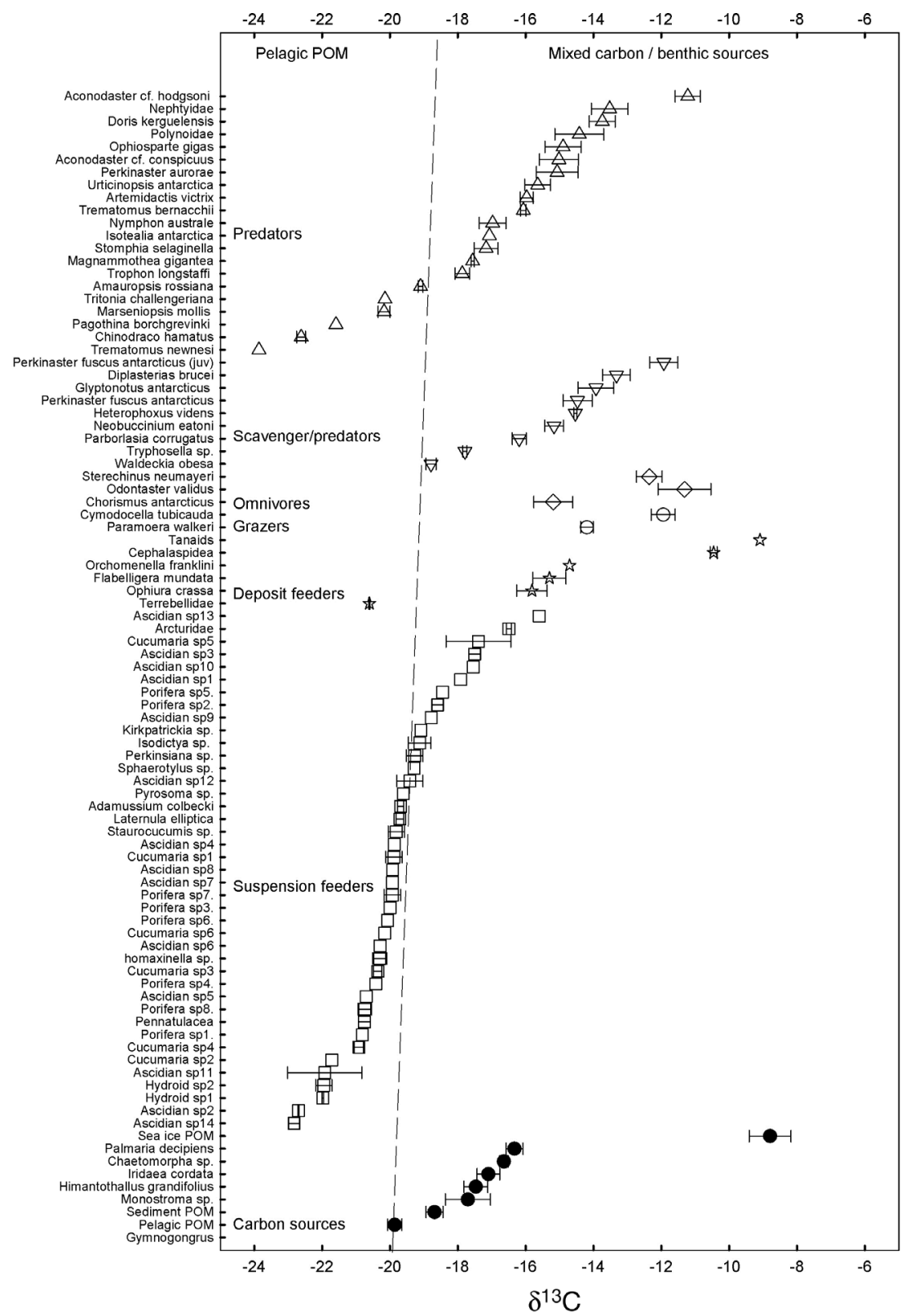

Fig. 2. $\delta^{13} \mathrm{C}$ values (mean $\pm \mathrm{SE}$ ) of fauna delineated by trophic category. Dashed line represents pelagic/benthic carbon component offset by $0.3 \%$ per trophic level. $\Delta$ : predator; $\nabla$ : predator/scavenger; $\diamond$ : omnivore; 设: deposit feeder; O: grazer; $\square$ : suspension feeder; $\bullet$ carbon source. Gymnogongrus sp. $=-30.1 \%$ (not shown)

(Fig. 2.) Among suspension feeders, $\delta^{13} \mathrm{C}$ values ranged from $-22.83 \%$ to $-15.60 \%$, and were more closely aligned to the pelagic POM carbon value than macroalgae (Figs. $2 \& 6 \mathrm{~A}$ ). However, several species displayed enriched carbon values beyond the $\delta^{13} \mathrm{C}$ ratios of pelagic POM, most notably, several species of ascidians and poriferans (Fig. 2).

Deposit feeders spanned a considerable $\delta^{13} \mathrm{C}$ range, from $-20.61 \%$ for terrebellid polychaetes to $-10.46 \%$ for opisthobranchs and $-9.09 \%$ for tanaids. The remaining deposit feeders, Flabelligera mundata, Ophiura crassa, Orchomenella franklini, had similar $\delta^{13} \mathrm{C}$ values $(-14.70 \%$ to $-15.81 \%)$, which were enriched by approximately $3 \%$ over sediment
POM. The 2 grazer species, Paramoera walkeri and Cymodocella tubicauda, had $\delta^{13} \mathrm{C}$ values enriched by 2 to $4 \%$ over macroalgae.

The 3 omnivore species were relatively enriched in $\delta^{13} \mathrm{C}$, closely matching benthic carbon sources (Fig. 2). Scavenger/predators spanned a considerable $\delta^{13} \mathrm{C}$ range from $-18.79 \%$ for the amphipod Waldeckia obesa to $-11.93 \%$ for Perkinaster cf. fuscus antarcticus (juvenile). On the whole, $\delta^{13} \mathrm{C}$ values across scavenger/predators, were more representative of relatively enriched benthic carbon sources.

Predators spanned the full $\delta^{13} \mathrm{C}$ spectrum, indicating carbon sources derived from both benthic and pelagic sources and a wide range of diets (Tables S1 
Fig. 3. $\delta^{15} \mathrm{~N}$ values (mean $\pm \mathrm{SE}$ ) of fauna delineated by trophic category. $\Delta$ : predator; $\nabla$ : predator/ scavenger; $\diamond$ : omnivore; is: deposit feeder; O: grazer; $\square$ : suspension feeder; 0 : carbon source; TL: trophic level

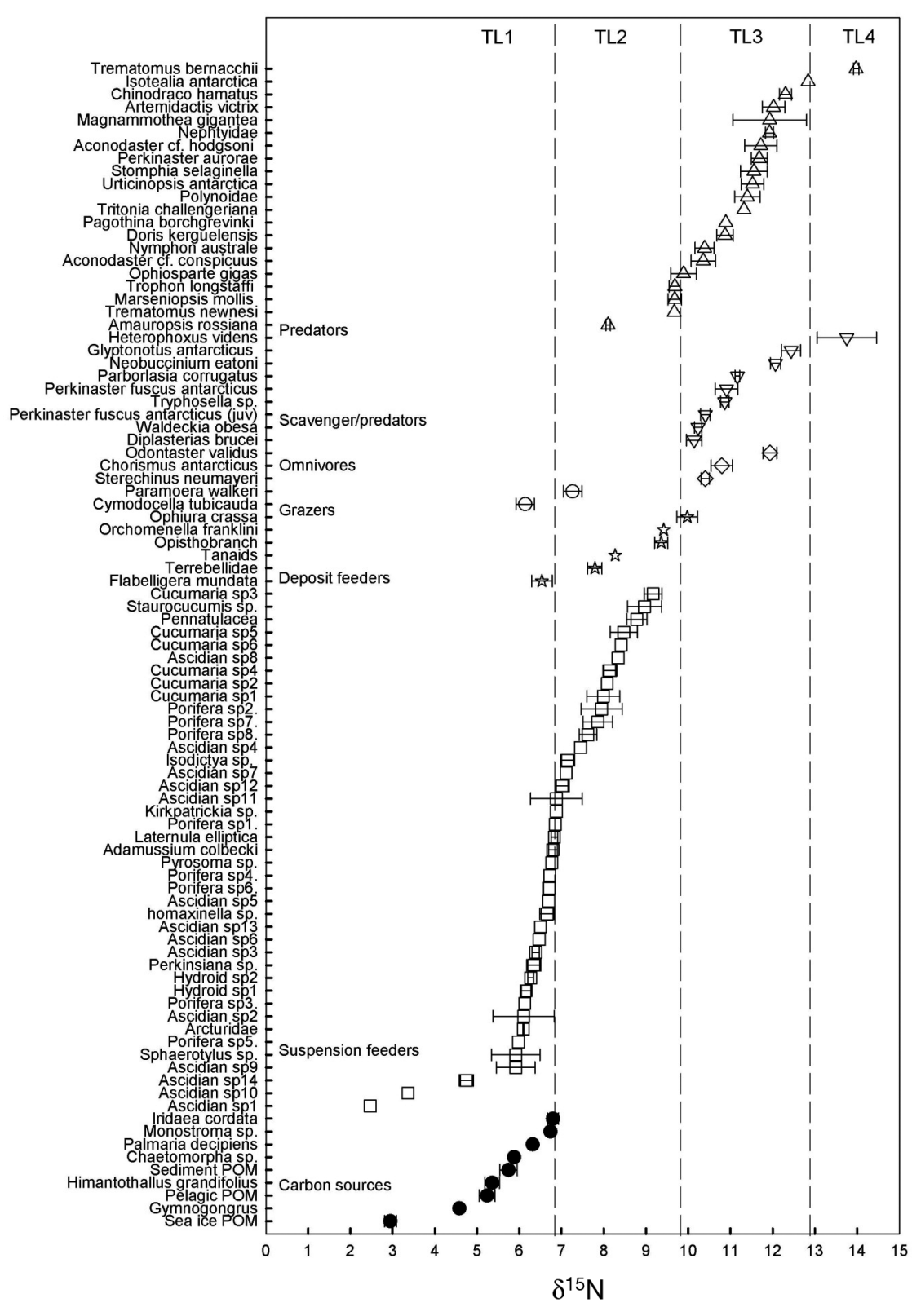

$\delta^{15} \mathrm{~N}$ in consumers

Nitrogen values amongst all consumers spanned a $\delta^{15} \mathrm{~N}$ range of $11.51 \%$, from $2.47 \%$ o for the Ascidian sp. 1 to $13.98 \%$ for the fish Trematomus bernacchii. Considerable variation occurred within most feeding guilds, with $\delta^{15} \mathrm{~N}$ values among members of the suspension-feeding, deposit-feeding, scavenger/ predators and predator guilds, spanning more than $3 \%$, equivalent to 1 trophic level (Fig. 3).

Based on the assumed 3\% enrichment per trophic level, the suspension-feeding guild spanned $6.17 \%$ or 2 trophic levels (Fig. 3). A considerable proportion of suspension feeders had $\delta^{15} \mathrm{~N}$ values greater than benthic carbon sources. 
the designated trophic baseline (Laternula elliptica, $6.83 \%$ ), notably several species of Cucumaria, Porifera, Pennatulacea and Staurocucumis sp., with Cucumaria sp. 3 having the highest $\delta^{15} \mathrm{~N}$ value amongst suspension feeders $(9.17 \%)$. Grazers, suspension feeders and deposit feeders were restricted to the second trophic level (first-order consumers) and differed in their isotopic values compared to second-order consumers (omnivores and predator/ scavengers, pairwise, $\mathrm{p}<0.01$ ), which were indistinguishable by $\delta^{15} \mathrm{~N}$ (means $11.04 \%$ and $11.38 \%$, respectively, $\mathrm{p}>0.01$ ).

Predators occupied the third trophic level (Figs. 3 \& 6A) with the mean $\delta^{15} \mathrm{~N}$ for the predator guild $(12.74 \%$ o) slightly, although significantly, higher compared to predator/scavengers and omnivores, $\mathrm{p}<0.01$ ). The fish Trematomus bernacchii and amphipod Heterophoxus videns had the highest $\delta^{15} \mathrm{~N}$ values (13.98\% and $13.76 \%$, respectively) although samples of $H$. videns were somewhat variable (Fig. 3). The $\delta^{15} \mathrm{~N}$ values of $T$. bernacchii were $7.15 \%$ more enriched than Laternula elliptica (trophic baseline), indicating the Vestfold Hills food web spans 4 trophic levels.

\section{Comparison with the Windmill Islands food web}

With the exception of Himantothallus grandifolius and Chaetomorpha sp., $\delta^{13} \mathrm{C}$ values among carbon sources were relatively similar for both regions (Fig. 4A). Neither region displayed consistent $\delta^{13} \mathrm{C}$ enrichment or depletion over the other location among carbon sources (Fig. $4 \mathrm{~A}$ ). However, $\delta^{13} \mathrm{C}$ val- ues were generally enriched amongst the Windmill Island fauna compared to those from the Vestfold Hills (Table 1, Fig. 4B).

Vestfold Hills carbon sources were consistently enriched in $\delta^{15} \mathrm{~N}$ compared to the same sources from the Windmill Islands, with a mean enrichment of $2 \%$ amongst producers between regions (range 0.10\% to $3.8 \%$ ) (Table 1, Fig. 5A). This trend continued amongst consumers, with $\delta^{15} \mathrm{~N}$ values consistently enriched by an average of $1.42 \%$ (range $0.43 \%$ to $5.75 \%$ ) (Table 1, Fig. 5B).

Several notable similarities occur between the Vestfold Hills food web and the isotope food web model developed for the Windmill Islands (Fig. 6A,B). Firstly, sea ice POM is substantially enriched compared to all other carbon sources and enrichment amongst POM carbon sources follows the trend: sea ice $\mathrm{POM}>$ sediment $\mathrm{POM}>$ pelagic $\mathrm{POM}$. Secondly, the suspension-feeding, deposit-feeding and grazer guilds occupy similar relative positions along the $\delta^{13} \mathrm{C}$ and $\delta^{15} \mathrm{~N}$ planes. Lastly, predators and scavenger/predators occupy a wide range of $\delta^{13} \mathrm{C}$ values, spanning the $\delta^{13} \mathrm{C}$ range of lower-order consumers, but share similar positions in the $\delta^{15} \mathrm{~N}$ plane, with predators only slightly enriched over predator/ scavengers and omnivores.

\section{DISCUSSION}

\section{Vestfold Hills food web}

We were successfully able to distinguish the main carbon sources and feeding guilds of the Vestfold
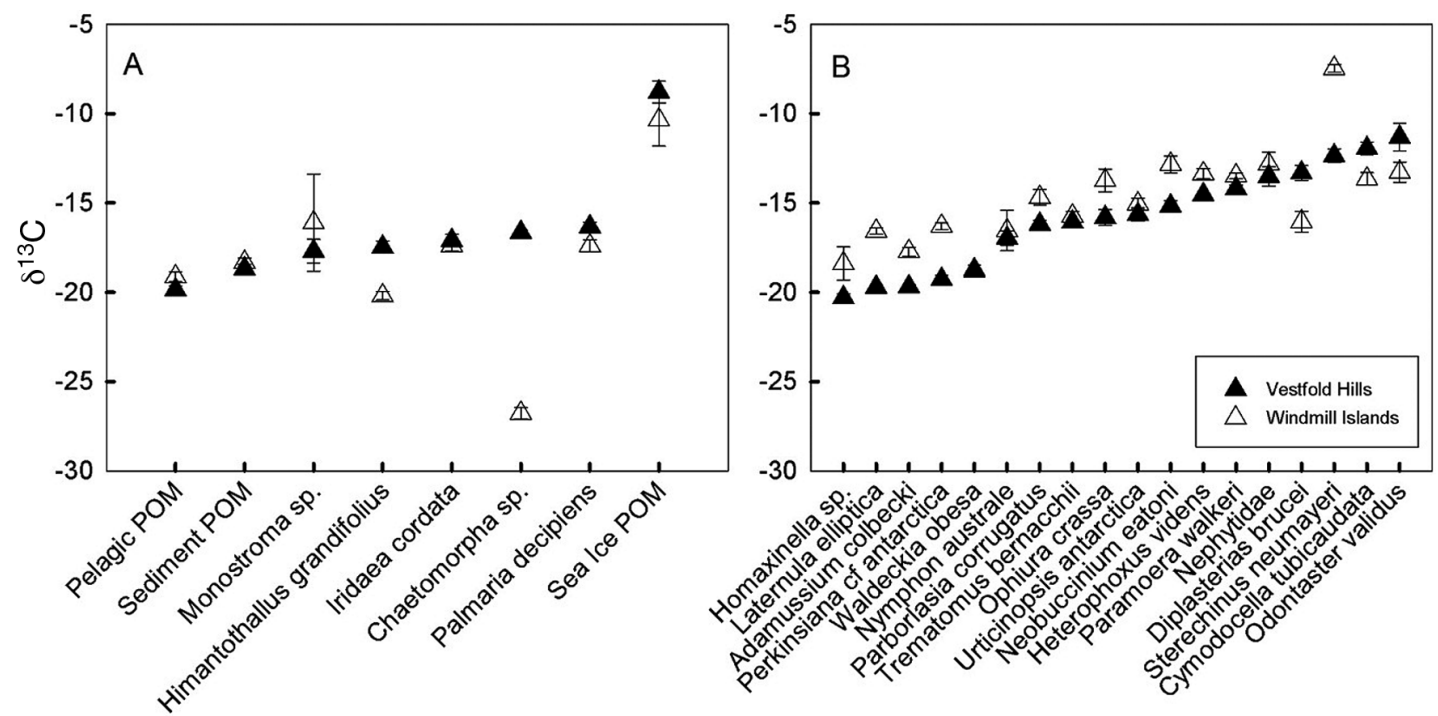

Fig. 4. $\delta^{13} \mathrm{C}$ comparisons of (A) carbon sources and (B) consumers from the Vestfold Hills and Windmill Islands 
Table 1. Results of statistical comparisons of $\delta^{15} \mathrm{~N}$ and $\delta^{13} \mathrm{C}$ isotope values of primary sources and consumers collected from the Vestfold Hills and Windmill Islands. *Significant p-values

\begin{tabular}{|c|c|c|c|c|}
\hline \multirow[t]{2}{*}{ Samples } & \multicolumn{2}{|c|}{ Sample size } & \multirow{2}{*}{$\begin{array}{l}\text { p-values for comparisons } \\
\text { of } \delta^{15} \mathrm{~N} \text { values from Vestfold Hills } \\
\text { and Windmill Islands }\end{array}$} & \multirow{2}{*}{$\begin{array}{c}\mathrm{p} \text {-values for comparisons } \\
\text { of } \delta^{13} \mathrm{C} \text { values from Vestfold Hills } \\
\text { and Windmill Islands }\end{array}$} \\
\hline & $\begin{array}{l}\text { Vestfold } \\
\text { Hills }\end{array}$ & $\begin{array}{l}\text { Windmill } \\
\text { Islands }\end{array}$ & & \\
\hline \multicolumn{5}{|l|}{ Carbon source } \\
\hline Chaetomorpha sp. & 6 & 4 & 0.755 & $0.010^{*}$ \\
\hline Monostroma sp. & 6 & 11 & 0.19 & 0.476 \\
\hline Himantothallus grandifolius & 6 & 9 & $<0.001^{*}$ & $<0.001^{*}$ \\
\hline Iridaea cordata & 18 & 18 & $<0.001^{*}$ & 0.566 \\
\hline Palmaria decipiens & 6 & 22 & $<0.001^{*}$ & 0.14 \\
\hline Pelagic POM & 6 & 8 & $<0.001^{*}$ & 0.142 \\
\hline Sea ice POM & 47 & 17 & 0.467 & 0.354 \\
\hline Sediment POM & 19 & 24 & $<0.001^{*}$ & 0.332 \\
\hline \multicolumn{5}{|l|}{ Consumers } \\
\hline Adamussium colbecki & 2 & 8 & $0.037^{*}$ & $0.001^{*}$ \\
\hline Cymodocella tubicauda & 2 & 6 & $0.017^{*}$ & 0.022 \\
\hline Diplasterias brucei & 11 & 11 & $<0.001^{*}$ & $0.001^{*}$ \\
\hline Heterophoxus videns & 2 & 10 & $0.003^{*}$ & 0.057 \\
\hline Homaxinella sp. & 5 & 4 & 0.503 & 0.126 \\
\hline Laternula elliptica & 8 & 21 & $0.01^{*}$ & $<0.001^{*}$ \\
\hline Neobuccinium eatoni & 18 & 12 & $0.009^{*}$ & $<0.001^{*}$ \\
\hline Nephtyidae & 3 & 5 & 0.885 & 0.465 \\
\hline Nymphon australe & 8 & 2 & 0.293 & 0.652 \\
\hline Odontaster validus & 9 & 2 & $0.001^{*}$ & 0.214 \\
\hline Ophiura crassa & 3 & 11 & $0.008^{*}$ & 0.097 \\
\hline Paramoera walkeri & 4 & 23 & $<0.001^{*}$ & 0.051 \\
\hline Parborlasia corrugatus & 5 & 9 & $0.002^{*}$ & $0.023^{*}$ \\
\hline Perkinsiana sp. & 8 & 36 & 0.773 & $<0.001^{*}$ \\
\hline Sterechinus neumayeri & 12 & 21 & $<0.001^{*}$ & $<0.001^{*}$ \\
\hline Trematomus bernacchii & 131 & 64 & $<0.001^{*}$ & 0.184 \\
\hline Urticinopsis antarctica & 11 & 14 & $0.008^{*}$ & 0.241 \\
\hline Waldeckia obesa & 3 & 4 & $0.004^{*}$ & 0.884 \\
\hline
\end{tabular}

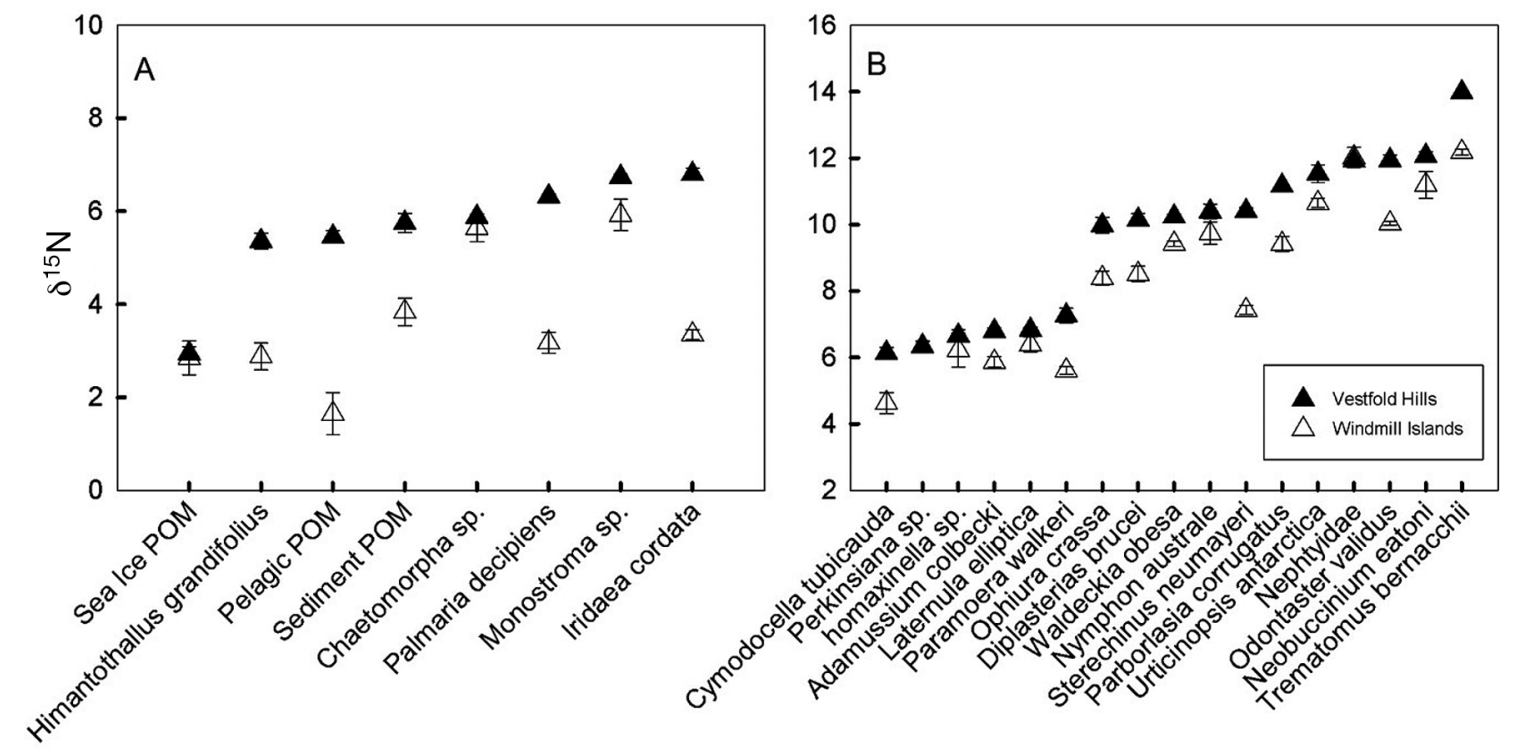

Fig. 5. $\delta^{15} \mathrm{~N}$ comparisons of (A) carbon sources and (B) consumers from the Vestfold Hills and Windmill Islands (note differences in $y$-axes) 

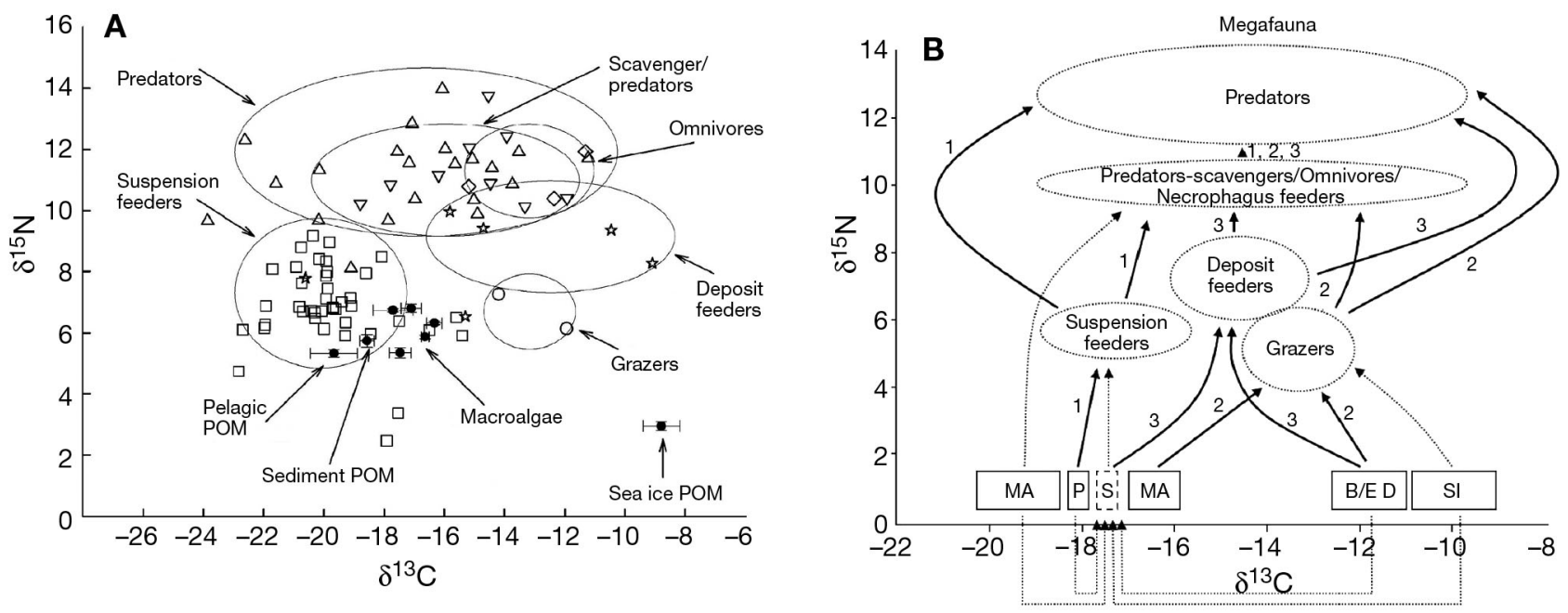

Fig. 6. (A) Stable isotope values of carbon $\left(\delta^{13} \mathrm{C}\right)$ and nitrogen $\left(\delta^{15} \mathrm{~N}\right)$ in carbon sources and consumers from the Vestfold Hills, and (B) trophic model of the Windmill Islands food web delineating the 3 major carbon pathways (reproduced from Gillies et al. 2012b): (1) Pelagic POM, suspension feeders and their predators; (2) Macroalgae and epiphytic algae, grazers and their predators; (3) Sediment POM, macroalgal detritus and benthic diatoms, deposit feeders and their predators. MA: macroalgae; P: pelagic particulate organic matter (POM); S: sediment POM; B/E D: benthic/epiphytic diatoms; SI: sea ice POM. Dotted lines represent minor contributions of carbon, and solid lines represent major flows of carbon. $x$ - and $y$-axes represent the boundaries of ecological niche space as defined by isotopic values (see Bearhop et al. 2004 and Layman et al. 2007).

Hills food web through the use of stable isotope analysis. Lower-order consumers could be grouped according to their feeding guild and main food sources whilst higher-order consumers occupied the full range of $\delta^{13} \mathrm{C}$ ratios, indicating energy at higher trophic levels originates from both benthic and pelagic carbon sources. Omnivores were restricted towards the enriched end of the $\delta^{13} \mathrm{C}$ axis, indicating a distinct origin of benthic food sources. There was little $\delta^{15} \mathrm{~N}$ trophic partitioning amongst predators, scavenger/ predators and omnivores, although higher-order guilds were more enriched in $\delta^{15} \mathrm{~N}$ compared to lower-order guilds, consistent with their higher feeding status.

\section{Carbon flow in the Vestfold Hills benthic community}

The $\delta^{13} \mathrm{C}$ values of suspension feeders were closely aligned with the depleted $\delta^{13} \mathrm{C}$ values in pelagic POM (Fig. 2), confirming that the majority of carbon utilised by suspension feeders is derived from pelagic production. Yet there was considerable intraguild variation in $\delta^{13} \mathrm{C}(7 \%)$, suggesting that other carbon sources are incorporated by at least some suspension feeders. Dietary variation among Antarctic suspension feeders is not unusual (Gili \& Coma 1998, Gili et al. 2001) and is likely to be a result of extreme temporal and spatial variability in primary food sources. For example, Norkko et al. (2007) showed that Laternula elliptica and Adamussium colbecki can have variable diets, switching between sea ice POM and detritus, in response to environmental gradients in food supply. Ahn (1997) recorded that benthic diatoms, in addition to phytoplankton, constitute a considerable portion of the diet of L. elliptica during summer, whilst smaller-sized plankton fractions and resuspended sediment POM sustain some suspension feeders during periods of limited food supply over winter (Barnes \& Clarke 1995).

Grazers and deposit feeders were clearly separated from suspension feeders on the $\delta^{13} \mathrm{C}$ axis, reflecting very different food sources. The $\delta^{13} \mathrm{C}$ values of grazers were, on average, 5 to $6 \%$ more enriched than pelagic POM, demonstrating a diet based on benthic carbon sources. However, we found a mismatch between the $\delta^{13} \mathrm{C}$ values of deposit feeders and grazers and the $\delta^{13} \mathrm{C}$ values of their (bulk) potential food sources. Gillies et al. (2012b) found a similar mismatch between $\delta^{13} \mathrm{C}$ values in deposit feeders and sediment POM, which may indicate that Antarctic deposit feeders actively select different carbon fractions based on their foraging location (Davenport 1988, Blazewicz-Paszkowycz \& Ligowski 2002, McMahon et al. 2006). Furthermore, deposit feeders may additionally or only assimilate/digest specific fractions of organic matter ingested (Purinton et al. 2008). Our results indicate that $\delta^{13} \mathrm{C}$ and $\delta^{15} \mathrm{~N}$ analysis of bulk sediment POM samples does not provide 
enough resolution to determine specific diet for deposit feeders, although $\delta^{13} \mathrm{C}$ values can clearly distinguish deposit feeders from other first-order consumers. Future studies should look to include ${ }^{14} \mathrm{C}$ analysis, gut content or gut DNA analysis, in combination with morphological analysis, to clearly determine diet in deposit feeders.

We suspect several carbon sources not collected in this study account for the difference in $\delta^{13} \mathrm{C}$ between grazers and macroalgae, with these sources likely occupying the $\delta^{13} \mathrm{C}$ position between benthic macroalgae and sea ice POM. For example, Corbisier et al. (2004) found benthic diatoms had $\delta^{13} \mathrm{C}$ values enriched by $7 \%$ over macroalgae and $9 \%$ over pelagic POM, whilst Dunton (2001) found epiphytic algae had $\delta^{13} \mathrm{C}$ values enriched by 2 to $6 \%$ over identical macroalgal species collected in this study. Benthic diatoms and epiphytic algae have been shown to be an important food source in other Antarctic shallowwater regions (Iken 1999, Kaehler et al. 2000, Zacher et al. 2007), possibly due to the lack of chemical defences in comparison to most Antarctic macroalgae (Amsler et al. 2005). We suggest they are equally likely to be important components of the Vestfold Hills food web and advise future studies to ensure they are represented as carbon sources.

Predator and scavenger/predator $\delta^{13} \mathrm{C}$ values spanned the carbon spectrum, signifying that higher trophic orders are ultimately reliant upon energy from several sources derived from both benthic and pelagic environments. Our results are consistent with those of other studies of Antarctic shallow-water communities conducted on the Antarctic Peninsula (Kaehler et al. 2000, Dunton 2001, Corbisier et al. 2004) and the Ross Sea (Norkko et al. 2007), which found that consumers occupy similar trophic levels but obtain their carbon from different sources. This is in contrast to benthic communities occupying the Antarctic shelf, where productivity is largely driven by sinking phytoplankton detritus (Jarre-Teichmann et al. 1997, Mincks et al. 2008).

We note that sea ice POM was particularly enriched in $\delta^{13} \mathrm{C}$ signatures, as has previously been identified at the Vestfold Hills (Gibson et al. 1999) and in the Ross Sea (Cozzi \& Cantoni 2011). The exact causes of isotopic variability in sea ice POM have been linked to temporal differences in the age of POM. Negative values are more reflective of winter ice minima, and enriched values more reflective of the summer algal bloom, due to reduced $\mathrm{CO}_{2}$ availability in brine channels and the ice/water interface during periods of high productivity (Gibson et al. 1999, Cozzi \& Cantoni 2011).
Trophic structure

The $\delta^{15} \mathrm{~N}$ values of predators, scavenger/predators and omnivores were similar, indicating little trophic separation amongst these guilds, but they were enriched over suspension feeders, deposit feeders and grazers by approximately $3.0 \%$, or 1 trophic level. The fish Trematomus bernacchii and amphipod Heterophoxus videns were enriched over all other benthic predators by approximately $2.5 \%$, signifying that the benthic food web occupies a trophic range of 4 levels. However, we noted an almost incremental range of $\delta^{15} \mathrm{~N}$ ratios amongst the fauna. The lack of any distinct grouping along the $\delta^{15} \mathrm{~N}$ axis (Fig. 3) suggests a trophic continuum (France et al. 1998) rather than traditional stepwise trophic models (Hairston et al. 1960). Trophic continua have previously been demonstrated in shallow water communities from the Antarctic Peninsula (Kaehler et al. 2000, Corbisier et al. 2004, Jacob et al. 2006), East Antarctica (Gillies et al. 2012b) and the continental shelf (Mincks et al. 2008), suggesting few guilds are tightly coupled with specific food sources.

\section{Vestfold Hills and Windmill Islands food webs}

Despite variable $\delta^{13} \mathrm{C}$ values amongst some carbon sources, the food webs for the Vestfold Hills and Windmill Islands displayed surprisingly similar characteristics to each other and to food webs developed for Antarctic coastal regions outside of East Antarctica. For both East Antarctic food webs, we found similar $(\leq 1.5 \%) \quad \delta^{13} \mathrm{C}$ values for pelagic POM, sea ice POM, sediment POM and 2 common red algae (Iridaea cordata, Palmaria decipiens), and, to a lesser extent, for the common brown alga Himantothallus grandifolius (2.5\%) (Fig. 4A). This led to a consistent scale of enrichment in $\delta^{13} \mathrm{C}$ amongst the main carbon sources in both food webs (i.e. sea ice POM > sediment $\mathrm{POM}>$ pelagic $\mathrm{POM}$ ), which is in agreement with other polar and Antarctic studies (Hobson et al. 2002, Corbisier et al. 2004). Furthermore, the Vestfold Hills and Windmill Islands food webs are represented by 4 trophic levels and a high degree of trophic omnivory among higher orders, consistent with food webs developed for benthic communities on the Antarctic Peninsula (Kaehler et al. 2000, Dunton 2001, Corbisier et al. 2004, Jacob et al. 2006). In both the Vestfold Hills and Windmill Island food webs, pelagic POM and macroalgal POM constituted the major food source for suspension feeders, whilst benthic and epiphytic diatoms were an additional food 
source for grazers and surface-deposit feeders. This is in agreement with Kaehler et al. (2000) and Dunton (2001), who estimated that between 25 and $68 \%$ of ingested material in suspension feeders is derived from macroalgae in food webs from Prince Edward Island and at several islands near Palmer Station. Corbisier et al. (2004) found microphytobenthos and sediment detritus contributed to the diets of benthic grazers in a food web from King George Island. Sea ice POM, despite its considerable biomass, appears to provide only a limited direct input of carbon into the benthic system, except for those species which are able to migrate to the underside of sea ice during winter months (e.g. Paramoera walkeri).

However, we found that the $\delta^{15} \mathrm{~N}$ values in carbon sources were consistently enriched at Vestfold Hills compared to the Windmill Islands (Fig. 5). This continued in consumers, despite time averaging and trophic enrichment associated with temporal variability and trophic fractionation in consumer tissue. These results imply source nitrogen in the Vestfold Hills food web is enriched in $\delta^{15} \mathrm{~N}$ compared to source nitrogen at the Windmill Islands, resulting in a food web-wide incremental shift in $\delta^{15} \mathrm{~N}$. Similar results have been found for other comparable food webs such as those affected by sewage (Hadwen \& Arthington 2007).

Enriched $\delta^{15} \mathrm{~N}$ values are largely the result of inorganic source nitrogen assimilation in producers, whereby ${ }^{14} \mathrm{~N}$ is preferentially selected over ${ }^{15} \mathrm{~N}$ during photosynthesis, when under non-limiting conditions (Michener \& Schell 1994). The $\delta^{15} \mathrm{~N}$ values of available inorganic source nitrogen may also vary spatially, and for marine systems, source nitrogen from deep waters is generally enriched compared to surface waters (Conway et al. 1994, Cabana \& Rasmussen 1996). Waters located close to upwelling zones may consequently have a sustained source of enriched source nitrogen compared to areas further away.

Although both the Vestfold Hills and Windmill islands share similar local characteristics (e.g. prevalence of rocky islands close to the coast, several shallow bays), there are considerable oceanographic differences which may account for variation in source nitrogen between the 2 locations. The Vestfold Hills lie on the eastern side of Prydz Bay, the third largest embayment on the Antarctic coast. Horizontal currents within the bay are dominated by a large, clockwise flowing gyre, connecting shelf and continental waters with the offshore circum-Antarctic current and a narrow, coastal current that flows west. The Vestfold Hills are located near the entry point of the gyre and coastal current, and hence, are likely to receive deep, nutrient rich (i.e. ${ }^{15} \mathrm{~N}$ enriched) waters (Nunes Vaz \& Lennon 1996). Local upwelling events in the vicinity of the Vestfold Hills can occur (Anilkumar et al. 2010), which may further increase the flow of deep water into shallow areas. In contrast, the Windmill Islands lie exposed on the coast and currents would be expected to vary considerably compared to those within Prydz Bay (i.e. lack of gyres and large ocean upwelling). Unfortunately, the lack of physical oceanographic data from the Windmill Islands precludes further analysis; nevertheless, our results highlight the possible effect of large-scale oceanographic processes on food webs represented by stable isotopes and indicate that such processes need to be considered in large-scale comparative analysis of food webs constructed using stable isotopes.

\section{General applicability of the model}

Our descriptive model is limited by the lack of data available for biomass, abundance and seasonality, restricting our ability to produce a truly comparative model which can be used to quantify changes within and across systems. Nevertheless, this study takes the first steps toward generating such a model for Antarctic shallow-water communities. Quantitative data is only available in Eastern Antarctica for infaunal communities located in the Windmill Islands, primarily as a result of examination into the impacts of Casey Station's sewage outfall and nearby rubbish tip (Stark et al. 2003).

Despite a lack of quantifiable data for epibenthic fauna, both food webs described in this study share similar attributes to other food webs described for benthic communities around Antarctica. We draw several observations about Antarctic benthic food webs in order to improve future research and discussion: (1) Antarctic benthic food webs are governed by a wide range in $\delta^{13} \mathrm{C}$ values, reflecting the variety of food sources utilised by consumers. Our wide range in $\delta^{13} \mathrm{C}$ values is consistent with those from both shelf (Nyssen et al. 2002, Mincks et al. 2008) and shallow waters (Dunton 2001, Corbisier et al. 2004), indicating benthic consumers are able to utilise a wide range of carbon sources, available as either fresh and/or detrital matter. (2) Detrital matter (including resuspended matter) sustains much of the benthic community during the winter months. During periods of high productivity in shelf communities, detritus is accumulated faster than it is consumed by the benthos, sustaining an ecological 'food bank' for the ben- 
thos during periods of low productivity (Mincks et al. 2005). Whilst no comparative research has been conducted for shallow-water communities, our study supports the notion that detritus is consumed by a considerable proportion of the benthos and we see no reason to doubt that (at least for fauna occupying the zone in which detritus is resuspended) a food bank would not also sustain many fauna occupying shallow waters. (3) Omnivory is a common trait in species that could be considered primarily deposit (detritus) feeders, herbivores or predators. Whilst no systematic review of omnivory in Antarctic species has been conducted (but see Arntz et al. 1994, McClintock 1994), omnivory is considered a common strategy for many consumers to combat variable food supplies. Our results support this observation in that several species had variable isotopic values amongst individuals (Tables S1 \& S2 in the supplement), whilst both food webs also had a number of species with $\delta^{13} \mathrm{C}$ values offset from singular food sources. (4) Shallow water food webs have a greater diversity of consumers occupying higher trophic levels (i.e. TL3 to TL4) compared to shelf communities. Whilst we acknowledge this observation is dependent on sampling effort, both the Vestfold Hills and Windmill Island food webs had a rich diversity of consumers with high $\delta^{15} \mathrm{~N}$ values (i.e. asteroids, polychaetes, crustaceans, fish), which also occurs in other shallowwater food webs (Kaehler et al. 2000, Jacob et al. 2006) yet is in contrast to shelf communities which have lower predator diversity (Jarre-Teichmann et al. 1997, Mincks et al. 2008). (5) Benthic food webs average 4 trophic levels in both shelf and shallow water habitats. Based on $\delta^{15} \mathrm{~N}$ values and food chain length, both the Vestfold Hills and Windmill Island food webs have 4 trophic levels, which is consistent with other benthic food webs developed for shallowwater and shelf communities (Jarre-Teichmann et al. 1997, Kaehler et al. 2000, Dunton 2001, Jacob et al. 2006, Mincks et al. 2008).

Whilst these observations are based on, for the large part, qualitative information, they serve at the very least to direct future effort towards priority research that is beneficial to both the general field of ecology and for management bodies, in light of rapidly changing ecosystems. Improvements in our knowledge of both small-scale and large-scale movements of carbon, the components and use of detritus amongst different feeding groups and shifts in carbon use under different environmental (specifically sea ice) conditions (in addition to basic ecological information such as abundance, biomass and seasonality) would rapidly advance our understanding of carbon flow in Antarctic benthic communities and simultaneously improve the comparability of food web models derived from stable isotopes.

\section{CONCLUSION}

The benthic community of the Vestfold Hills obtains its energy from several carbon sources of both pelagic and benthic origins and displayed similar characteristics to that described for the Windmill Islands. The relative positioning of each feeding guild on the isotopic bi-plots is similar for both food webs, indicating stable isotopes are able to summarise similar aspects of carbon flow and trophic position across large spatial scales. In both food webs, suspension feeders occupied a similar position with depleted $\delta^{13} \mathrm{C}$ and $\delta^{15} \mathrm{~N}$ values, whilst grazers occupied the same trophic position but were enriched in $\delta^{13} \mathrm{C}$, corresponding with differences in diet. These consistencies demonstrate that isotopederived food webs describing similar communities are able to display consistent properties, facilitating Antarctic-wide generalisations about community structure and function. Further analysis with studies conducted from other regions in Antarctica would prove fruitful in refining a representative food web model for Antarctic, shallow-water ecosystems. Such a model would provide a trophic benchmark against which modification in these communities brought about by climate change or other human impacts could be compared.

Acknowledgements. Members of 2009 and 2010 summer Davis field and diving teams provided endless assistance with all field collections. Advice on stable isotope preparation was provided by H. Stuart-Williams. Fig. 1 was produced by K. James from maps provided by the Australian Antarctic Data Centre. We are grateful to the 4 anonymous reviewers for very insightful and thorough comments that greatly improved the content of this manuscript. This research was funded by a $\mathrm{PhD}$ Research Scholarship from Southern Cross University and supported financially and logistically by the Australian Antarctic Division (AAS projects 2948 and 2201). Additional support and funding was provided by the Marine Ecology Research Centre at Southern Cross University.

\section{LITERATURE CITED}

Ahn I (1997) Feeding ecology of the Antarctic lamellibranch Laternula elliptica (Laternulidae) in Marian Cove and vicinity King George Island, during one austral summer. In: Battaglia B, Valencia J, Walton DWH (eds) Antarctic communities: species structure and survival. Cambridge University Press, Cambridge, p 142-151 
Amsler CD, Iken K, McClintock JB, Amsler MO and others (2005) Comprehensive evaluation of the palatability and chemical defenses of subtidal macroalgae from the Antarctic Peninsula. Mar Ecol Prog Ser 294:141-159

Anderson MJ (2001) Permutation tests for univariate or multivariate analysis of variance and regression. Can J Fish Aquat Sci 58:626-639

Anilkumar N, Mohan R, Shukla SK, Pednekar S, Sudhakar M, Ravindra R (2010) Signature of coastal upwelling in Prydz Bay, East Antarctica during austral summer 2006. Curr Sci 99:1390-1394

Arntz W, Brey T, Gallardo VA (1994) Antarctic zoobenthos. Oceanogr Mar Biol Annu Rev 32:241-304

> Barbraud C, Weimerskirch H (2001) Emperor penguins and climate change. Nature 411:183-186

Barnes DKA (1999) The influence of ice on the polar nearshore benthos. J Mar Biol Assoc UK 79:401-407

> Barnes DKA, Clarke A (1995) Seasonality of feeding activity in Antarctic suspension feeders. Polar Biol 15:335-340

> Barnes D, Linse K, Waller C, Morely S, Enderlein P, Fraser K, Brown M (2006) Shallow benthic fauna communities of South Georgia Island. Polar Biol 29:223-228

Bearhop S, Adams CE, Waldron S, Fuller RA, MacLeod H (2004) Determining trophic niche width: a novel approach using stable isotope analysis. J Anim Ecol 73:1007-1012

Blazewicz-Paszkowycz M, Ligowski R (2002) Diatoms as food source indicator for some Antarctic Cumacea and Tanaidacea (Crustacea). Antarct Sci 14:11-15

Cabana G, Rasmussen JB (1996) Comparison of aquatic food chains using nitrogen isotopes. Proc Natl Acad Sci USA 93:10844-10847

> Clarke A (1988) Seasonality in the Antarctic marine environment. Comp Biochem Physiol B 90:461-473

Conway NM, Kennicutt IMC, Van Dover CL (1994) Stable isotopes in the study of marine chemosynthetic-based ecosystems. In: Lajtha K, Michener R (eds) Stable isotopes in ecology and environmental science. Blackwell Scientific Publications, London, p 158-186

Corbisier T, Petti MV, Skowronski RP, Brito TS (2004) Trophic relationships in the nearshore zone of Martel Inlet (King George Island, Antarctica): $\delta^{13} \mathrm{C}$ stable-isotope analysis. Polar Biol 27:75-82

> Cozzi S, Cantoni C (2011) Stable isotope $\left(\delta^{13} \mathrm{C}\right.$ and $\left.\delta^{15} \mathrm{~N}\right)$ composition of particulate organic matter, nutrients and dissolved organic matter during spring ice retreat at Terra Nova Bay. Antarct Sci 23:43-56

Davenport J (1988) The feeding mechanism of Yoldia (= Aequiyoldia) eightsi (Courthouy). Proc R Soc Lond B Biol Sci 232:431-442

> Dayton PK, Oliver JS (1977) Antarctic soft-bottom benthos in oligotrophic and eutrophic environments. Science 197:55-58

> Dayton PK, Gordon AR, Paine RT, Dayton LB (1974) Biological accommodation in the benthic community at McMurdo Sound, Antarctica. Ecol Monogr 44:105-128

Dayton PK, Mordida BJ, Bacon F (1994) Polar marine communities. Am Zool 34:90-99

> DeNiro MJ, Epstein S (1977) Mechanism of carbon isotope fractionation associated with lipid synthesis. Science 197: 261-263

> Dunton KH (2001) $\delta^{15} \mathrm{~N}$ and $\delta^{13} \mathrm{C}$ measurements of Antarctic Peninsula fauna: trophic relationships and assimilation of benthic seaweeds. Am Zool 41:99-112

France R, Chandler M, Peters R (1998) Mapping trophic continua of benthic foodwebs: body size- $\delta^{15} \mathrm{~N}$ relationships. Mar Ecol Prog Ser 174:301-306
Gambi MC, Lorenti M, Russo GF, Scipione MB (1994) Benthic associations of the shallow hard bottoms off Terra Nova Bay, Ross Sea: zonation, biomass and population structure. Antarct Sci 6:449-462

Gibson JAE, Trull T, Nichols PD, Summons RE, McMinn A (1999) Sedimentation of ${ }^{13} \mathrm{C}$-rich organic matter from Antarctic sea-ice algae: A potential indicator of past seaice extent. Geology 27:331-334

Gili JM, Coma R (1998) Benthic suspension feeders: their paramount role in littoral marine food webs. Trends Ecol Evol 13:316-321

> Gili JM, Coma R, Orejas C, López-González P, Zabala M (2001) Are Antarctic suspension-feeding communities different from those elsewhere in the world? Polar Biol 24:473-485

Gillies C, Stark J, Smith S (2012a) Small-scale spatial variation of $\delta^{13} \mathrm{C}$ and $\delta^{15} \mathrm{~N}$ isotopes in Antarctic carbon sources and consumers. Polar Biol 35:813-827

Gillies CL, Stark JS, Johnstone GJ, Smith SDA (2012b) Carbon flow and trophic structure of an Antarctic coastal benthic community as determined by $\delta^{13} \mathrm{C}$ and $\delta^{15} \mathrm{~N}$. Estuar Coast Shelf Sci 97:44-57

Gutt J (2007) Antarctic macro-zoobenthic communities: a review and an ecological classification. Antarct Sci 19: 165-182

Hadwen WL, Arthington AH (2007) Food webs of two intermittently open estuaries receiving ${ }^{15} \mathrm{~N}$-enriched sewage effluent. Estuar Coast Shelf Sci 71:347-358

Hairston NG, Smith FE, Slobodkin LB (1960) Community structure, population control, and competition. Am Nat 94:421-425

Hobson KA, Fisk A, Karnovsky N, Holst M, Gagnon JM, Fortier M (2002) A stable isotope $\left(\delta^{13} \mathrm{C}, \delta^{15} \mathrm{~N}\right)$ model for the North Water food web: implications for evaluating trophodynamics and the flow of energy and contaminants. Deep-Sea Res II 49:5131-5150

Iken K (1999) Feeding ecology of the Antarctic herbivorous gastropod Laevilacunaria antarctica Martens. J Exp Mar Biol Ecol 236:133-148

> Jacob U, Mintenbeck K, Brey T, Knust R, Beyer K (2005) Stable isotope food web studies: a case for standardized sample treatment. Mar Ecol Prog Ser 287:251-253

> Jacob U, Brey T, Fetzer I, Kaehler S and others (2006) Towards the trophic structure of the Bouvet Island marine ecosystem. Polar Biol 29:106-113

Jarre-Teichmann A, Brey T, Bathman U, Dahm C and others (1997) Trophic flows in the benthic shelf community of the eastern Weddell Sea, Antarctica. In: Battaglia B, Valencia J, Walton D (eds) Antarctic communities: species, structure and survival. Cambridge University Press, Cambridge, p 118-134

Johnston E, Connell S, Irving A, Pile A, Gillanders B (2007) Antarctic patterns of shallow subtidal habitat and inhabitants in Wilke's Land. Polar Biol 30:781-788

Kaehler S, Pakhomov EA, McQuaid CD (2000) Trophic structure of the marine food web at the Prince Edward Islands (Southern Ocean) determined by $\delta^{13} \mathrm{C}$ and $\delta^{15} \mathrm{~N}$ analysis. Mar Ecol Prog Ser 208:13-20

Layman C, Arrington D, Montaña C, Post D (2007) Can stable isotope ratios provide for community-wide measures of trophic structure. Ecology 88:42-48

Macdonald RW, Harner T, Fyfe J (2005) Recent climate change in the Arctic and its impact on contaminant pathways and interpretation of temporal trend data. Sci Total Environ 342:5-86 
Massom RA, Stammerjohn SE (2010) Antarctic sea ice change and variability - physical and ecological implications. Polar Sci 4:149-186

McCann KS (2000) The diversity-stability debate. Nature 405:228-233

McClintock JB (1994) Trophic biology of antarctic shallowwater echinoderms. Mar Ecol Prog Ser 111:191-202

- McMahon KW, Ambrose WG Jr., Johnson BJ, Sun MY, Lopez GR, Clough LM, Carroll ML (2006) Benthic community response to ice algae and phytoplankton in $\mathrm{Ny}$ Ålesund, Svalbard. Mar Ecol Prog Ser 310:1-14

Michener R, Schell DM (1994) Stable isotopes as tracers in marine aquatic food webs. In: Lajtha $\mathrm{K}$, Michener R (eds) Stable isotopes in ecology and environmental science. Blackwell Scientific Publications, London, p 138-157

Mincks SL, Smith CR, DeMaster DJ (2005) Persistence of labile organic matter and microbial biomass in Antarctic shelf sediments: evidence of a sediment 'food bank'. Mar Ecol Prog Ser 300:3-19

> Mincks SL, Smith CR, Jeffreys RM, Sumida PYG (2008) Trophic structure on the West Antarctic Peninsula shelf: detritivory and benthic inertia revealed by $\delta^{13} \mathrm{C}$ and $\delta^{15} \mathrm{~N}$ analysis. Deep-Sea Res II 55:2502-2514

Moran MD (2003) Arguments for rejecting the sequential Bonferroni in ecological studies. Oikos 100:403-405

Murray MD, Luders DJ (1990) Faunistic studies at the Windmill Islands, Wilkes Land, East Antarctica, 1959-80. ANARE Research Notes 73

Norkko A, Thrush SF, Cummings V, Gibbs HL, Andrew N, Norkko J, Schwarz AM (2007) Trophic structure of coastal Antarctic food webs associated with changes in sea ice and food supply. Ecology 88:2810-2820

> Nunes Vaz RA, Lennon GW (1996) Physical oceanography of the Prydz Bay region of Antarctic waters. Deep-Sea Res I 43:603-641

Nyssen F, Brey T, Lepoint G, Bouquegneau JM, De Broyer C, Dauby P (2002) A stable isotope approach to the eastern Weddell Sea trophic web: focus on benthic amphipods. Polar Biol 25:280-287

Peck LS (2005) Prospects for surviving climate change in Antarctic aquatic species. Front Zool 2:9

Polis GA (1994) Food webs, trophic cascades and community structure. Aust J Ecol 19:121-136

Post DM (2002) Using stable isotopes to estimate trophic

Editorial responsibility: William Kemp,

Cambridge, Maryland, USA position: models, methods and assumptions. Ecology 83: 703-718

Post DM, Layman CA, Arrington DA, Takimoto G, Quattrochi J, Montaña CG (2007) Getting to the fat of the matter: models, methods and assumptions for dealing with lipids in stable isotope analyses. Oecologia 152:179-189

> Purinton BL, Demaster DJ, Thomas CJ, Smith CR (2008) ${ }^{14} \mathrm{C}$ as a tracer of labile organic matter in Antarctic benthic food webs. Deep-Sea Res II 55:2438-2450

> Quartino M, Boraso de Zaixso A (2008) Summer macroalgal biomass in Potter Cove, South Shetland Islands, Antarctica: its production and flux to the ecosystem. Polar Biol 31:281-294

Quinn G, Keough M (2002) Experimental design and data analysis for biologists, 1st edn. Cambridge University Press, Cambridge

Snape I, Riddle MJ, Stark JS, King CK, Duquesne S, Gore DB (2001) Management and remediation of contaminated sites at Casey Station, Antarctica. Polar Rec (Gr Brit) 37:199-214

Stammerjohn SE, Martinson DG, Smith RC, Iannuzzi RA (2008) Sea ice in the western Antarctic Peninsula region: spatio-temporal variability from ecological and climate change perspectives. Deep-Sea Res II 55:2041-2058

> Stark JS, Riddle MJ, Simpson RD (2003) Human impacts in soft-sediment assemblages at Casey Station, East Antarctica: spatial variation, taxonomic resolution and data transformation. Austral Ecol 28:287-304

Tucker MJ, Burton HR (1987) A survey of the marine fauna in shallow coastal waters of the Vestfold Hills and Rauer Islands, Antarctica. ANARE Res Notes 55

> Tucker MJ, Burton HR (1988) The inshore marine ecosystem off the Vestfold Hills, Antarctica. Hydrobiologia 165: 129-139

Underwood AJ (1997) Experiments in ecology: their logical design and interpretation using analysis of variance. Cambridge University Press, Cambridge

- Vander Zanden MJ, Rasmussen JB (2001) Variation in $\delta^{15} \mathrm{~N}$ and $\delta^{13} \mathrm{C}$ trophic fractionation: implications for aquatic food web studies. Limnol Oceanogr 46:2061-2066

Zacher K, Hanelt D, Wiencke C, Wulff A (2007) Grazing and UV radiation effects on an Antarctic intertidal microalgal assemblage: a long-term field study. Polar Biol 30: 1203-1212

Submitted: March 5, 2012; Accepted: December 4, 2012 Proofs received from author(s): March 10, 2013 